\title{
PENGARUH INTELLECTUAL CAPITAL TERHADAP KINERJA KEUANGAN PERUSAHAAN
}

\author{
Novita Febriany \\ Universitas Katolik Musi Charitas \\ novita@ukmc.ac.id
}

\begin{abstract}
The purpose of this study was to examine the effect of Intellectual Capital on the Company's Financial Performance in the Kompas 100 index companies listed on the Indonesia Stock Exchange. Multiple linear regression analysis is used as the analytical technique. The results of hypothesis testing (t-test) prove that Intellectual Capital influences the Company's Financial Performance. This means that the better the Intellectual Capital owned by the compass index company 100, the higher the company's financial performance.
\end{abstract}

Keywords: Intellectual Capital and Financial Performance.

\begin{abstract}
ABSTRAK
Tujuan penelitian ini adalah untuk menguji pengaruh Intellectual Capital terhadap kinerja keuangan perusahaan yang terdaftar dalam Kompas 100 index yang terdaftar pada on the Bursa Efek Indonesia. Analisis regresi berganda digunakan sebagai teknik analisis yang digunakan. Hasil pengujian hipotesis (uji t-test) menunjukkan bahwa Intellectual Capital berpengaruh positif terhadap kinerja keuangan perusahaan. Hal ini menunjukkan bahwa Intellectual Capital yang semakin baik yang dimiliki oleh perusahaan yang terdaftar dalam index Kompas 100, maka semakin tinggi pula kinerja keuangan perusahaan.
\end{abstract}

\section{PENDAHULUAN}

Sekarang ini, perkembangan bisnis semakin pesat yang disertai dengan perkembangan teknologi, sehingga perusahaan diharapkan dapat bersaing satu dengan yang lain. Menurut Aprisa (2016), dengan semakin berkembangnya teknologi informasi dan ilmu pengetahuan maka turut mengubah cara pandang perusahaan dalam menjalankan aktivitasnya guna menciptakan nilai perusahaan. Inovasi, teknologi informasi dan pengetahuan sumber daya manusia yang dimiliki perusahaan dinilai penting dalam proses penciptaan nilai dan peningkatan kemampuan bersaing (Nugroho, 2012). Dengan berkembangnya teknologi, para pelaku bisnis mulai menyadari bahwa pentingnya intellektual capital perusahaan, sehingga dapat meningkatkan kinerja keuangan perusahaan.

Intellectual capital (modal intelektual) adalah suatu bagian dari aset tidak berwujud yang dapat digunakan oleh perusahaan untuk menciptakan keunggulan bersaing. Modal intelektual dapat memberikan nilai tambah perusahaan apabila diimplementasikan dengan baik. Menurut Pulic (1998) dalam Ulum dkk (2008), tujuan utama dalam ekonomi yang berbasis pengetahuan adalah untuk menciptakan value added. Untuk menciptakan value added dibutuhkan ukuran yang tepat tentang physical capital (dana keuangan) dan intellectual potencial (direpresentasikan oleh karyawan dengan segala potensi dan kemampuan yang melekat pada mereka). Selain itu, resource based theory menyebutkan bahwa perusahaan memiliki sumber daya yang dapat menjadikan perusahaan memiliki keunggulan bersaing dan mampu mengarahkan perusahaan untuk memiliki kinerja jangka panjang yang baik. Resources yang berharga dapat diarahkan untuk menciptakan keunggulan bersaing, sehingga mampu bertahan lama dan tidak mudah ditiru, ditransfer atau digantikan (Walidayni, 2017). 
Fenomena modal intelektual di Indonesia telah ada sejak munculnya Pernyataan Standar Akuntansi Keuangan (PSAK) No.19 tentang aset tak berwujudAset tak berwujud adalah aset non-moneter teridentifikasi dan tidak memiliki wujud fisik, dimiliki untuk digunakan dalam menghasilkan atau menyerahkan barang dan jasa, disewakan kepada pihak lainnya, atau untuk tujuan administratif. Contoh dari aset tak berwujud adalah ilmu pengetahuan dan teknologi, lisensi, hak kekayaan intelektual dan merk dagang (Ikatan Akuntan Indonesia, 2016).

Penelitian mengenai intellectual capital yang dilakukan oleh Ulum dkk (2008) membuktikan bahwa intellectual capital berpengaruh terhadap kinerja keuangan perusahaan. Wijayani (2017) yang membuktikan bahwa intellectual capital berpengaruh positif signifikan terhadap ROA, EPS, dan ROE pada perusahaan manufaktur. Hal ini sejalan dengan penelitian Faradina (2016) dengan hasil penelitian intellectual capital berpengaruh terhadap kinerja keuangan perusahaan LQ45 periode 2010-2014 yang diukur dengan ROA. Namun, hasil peneltiian berbeda dengan yang dilakukan oleh Andriana (2014) yang menyimpulkan bahwa intellectual capital dan human capital berpengaruh negatif dan tidak signifikan terhadap kinerja keuangan perusahaan. Perbedaan hasil penelitian ini membuat peneliti ingin meneliti kembali untuk menguji apakah modal intelektual memiliki pengaruh terhadap kinerja keuangan perusahaan.

Penelitian ini merujuk pada Untara (2014) yang meneliti pengaruh modal intelektual terhadap kinerja keuangan perusahaan perbankan dengan hasil bahwa Value Added Capital Employed (VACA), Value Added Human Capital (VAHU) dan Structural Capital Value Added (STVA) berpengaruh terhadap ROA. Yang membedakan penelitian ini dengan penelitian Untara (2014) adalah pada populasi penelitian ini adalah perusahaan yang terdaftar dalam indeks Kompas100 di Bursa Efek Indonesia periode 2015-2017. Indeks Kompas100 dipilih dikarenakan pencapaian kinerja yang baik dibandingkan dengan perusahaan lain yang tidak tercatat dalam Kompas100. Menurut Utari 2016 didalam berita seputar forex menyatakan bahwa, Indeks Kompas100 adalah indeks saham di Bursa Efek Indonesia (BEI) yang terdiri dari 100 emiten dengan pemilihan berdasarkan faktor likuiditas, kapitalisasi pasar, dan kinerja fundamental yang mewakili $70-80 \%$ dari seluruh kapitalisasi pasar yang ada di BEI. Hal ini diharapkan dapat memberikan gambaran tentang kondisi keuangan perusahaan yang nyata dan relevan bagi para pemakai informasi. Selain itu, dilihat dari fenomena MAKE Study bahwa pemenang ajang tersebut merupakan dari berbagai sektor industri yang ada di indeks Kompas100. Hal ini menarik perhatian peneliti apakah perusahaan-perusahaan dari indeks Kompas 100 yang tidak memenangkan MAKE Study memiliki kinerja keuangan yang baik dikarenakan oleh penerapan modal intelektual. Berdasarkan uraian di atas, maka peneliti tertarik mengambil judul "Pengaruh Intellectual Capital terhadap Kinerja Keuangan Perusahaan".

\section{Perumusan masalah}

Berdasarkan uraian yang telah dijelaskan sebelumnya, maka dapat dinyatakan perumusan masalah dalam penelitian ini adalah: Apakah intellectual capital berpengaruh terhadap kinerja keuangan perusahaan yang terdaftar di indeks Kompas 100.

\section{TINJAUAN PUSTAKA DAN PENGEMBANGAN HIPOTESIS \\ Teori Stakeholder}

Stakeholder theory menyatakan bahwa perusahaan bukanlah entitas yang hanya beroperasi untuk kepentingan sendiri, namun harus memberikan manfaat kepada seluruh stakeholder-nya seperti pemegang saham, kreditor, konsumen, pemasok, pemerintah, masyarakat (Ghozali, 2007: 409). Tujuan dari teori stakeholder adalah 
membantu manajer mengerti dan melakukan pengelolaan dengan efektif di lingkungan perusahaan. Lebih lanjut, tujuan utama teori stakeholder adalah untuk meningkatkan nilai dari dampak aktivitas stakeholder dan meminimalkan kerugiankerugian bagi stakeholder tersebut (Ulum, 2012). Manajemen diharapkan melakukan aktivitas-aktivitas yang penting dan melaporkannya kembali kepada stakeholder. Semua pihak yang berkepentingan berhak untuk disediakan informasi tentang aktivitas perusahaan. Stakeholder menjadi pertimbangan suatu perusahaan untuk mengungkapkan atau tidak mengungkapkan informasi dalam laporan keuangan perusahaan.

\section{Resource Based Theory}

Resource Based Theory membahas tentang bagaimana sumber daya perusahaan dikelola dengan efektif dan efisien sehingga akhirnya dapat menciptakan keunggulan bersaing. Sumber daya yang kompeten dapat menjadikan perusahaan mampu bersaing dan memiliki keunggulan dari para pesaingnya. Perusahaan memiliki sumber daya yang dapat menjadikan perusahaan memiliki keunggulan bersaing dan mampu mengarahkan perusahaan untuk memiliki kinerja jangka panjang yang baik.

Resources yang berharga dapat diarahkan untuk menciptakan keunggulan bersaing, sehingga mampu bertahan lama dan tidak mudah ditiru, ditransfer atau digantikan. Oleh karena itulah modal intelektual menjadi kunci untuk menciptakan value added bagi perusahaan (Walidayni, 2017). Menurut Susanto (2007) dalam Angela (2016), dalam menentukan sumber daya kunci, Resource Based Theory memberikan beberapa kriteria, antara lain:

1. Sumber daya tersebut mampu mendukung kemampuan perusahaan dalam memenuhi kebutuhan pelanggan yang lebih baik dibandingkan dengan pesaing.

2. Sumber daya tersebut tersedia dalam jumlah terbatas atau langka dan tidak mudah ditiru. Terdapat empat karakteristik yang mengakibatkan sumber daya menjadi sulit ditiru, yaitu sumber daya tersebut unik secara fisik, memerlukan waktu yang lama dan biaya yang besar untuk memperolehnya, sumber daya unik yang sulit dimiliki dan dimanfaatkan pesaing, dan sumber daya yang memerlukan investasi modal yang besar untuk mendapatkannya.

3. Sumber daya tersebut dapat memberikan keuntungan bagi perusahaan. Semakin banyak keuntungan yang menjadi milik perusahaan akibat pemanfaatan sumber daya tertentu, maka semakin berharga sumber daya tersebut.

4. Daya tahan sumber daya, semakin lambat suatu sumber daya mengalami depresiasi, semakin berharga sumber daya tersebut.

\section{Modal Intelektual}

Menurut Sugeng (2002) dalam Wijayani (2017), modal intelektual mengacu pada pengetahuan dan kemampuan yang dimiliki suatu kolektivitas sosial seperti organisasi, komunitas intelektual, atau praktik profesional. Modal intelektual mampu mewakili sumber daya yang bernilai dan kemampuan untuk bertindak yang didasarkan pada pengetahuan. Sedangkan menurut Sawarjuwono dan Kadir (2003), modal intelektual dapat didefinisikan sebagai jumlah dari apa yang dihasilkan oleh tiga elemen utama organisasi (human capital, structural capital, customer capital) yang berkaitan dengan pengetahuan dan teknologi yang dapat memberikan nilai lebih bagi perusahaan berupa keunggulan bersaing organisasi.

Bontis et al (2000) dalam Ulum dkk (2008) menyatakan bahwa secara umum tiga komponen utama dari modal intelektual, yaitu: human capital, structural capital, dan customer capital. Secara sederhana human capital merepresentasikan individual knowledge stock suatu organisasi yang direpresentasikan oleh karyawannya. Structural capital meliputi seluruh non-human storehouses of knowledge dalam organisasi. Sedangkan customer capital adalah pengetahuan yang melekat dalam 
marketing channels dan customer relationship dimana suatu organisasi mengembangkannya melalui jalannya bisnis.

\section{Pengembangan Hipotesis}

Pengaruh Modal Intelektual Terhadap Kinerja Keuangan Perusahaan.

Modal intelektual adalah suatu bagian dari aset tidak berwujud yang dapat digunakan oleh perusahaan untuk menciptakan keunggulan bersaing. Modal intelektual dapat memberikan nilai tambah perusahaan apabila diimplementasikan dengan baik. Berdasarkan teori stakeholder, jika manajemen dapat mengelola dengan baik sumber daya yang ada, khususnya dalam upaya penciptaan nilai (value creation), maka berarti manajemen itu telah memenuhi unsur etika. Value creation dalam konteks ini adalah memanfaatkan seluruh potensi yang dimiliki perusahaan baik karyawan (human capital), aset fisik (physical capital), dan structural capital (Ulum, 2012). Pemanfaatan potensi secara menyeluruh dapat menciptakan nilai tambah (value added) bagi perusahaan dan mendorong kinerja perusahaan.

Selain itu, Resource Based Theory mengemukakan bahwa jika sumber daya perusahaan dikelola dengan efektif dan efisien sehingga akhirnya dapat menciptakan keunggulan bersaing. Modal intelektual berperan penting dalam meningkatkan kinerja keuangan. Pengelolaan modal fisik secara efektif dan efisien merupakan bagian dari pemanfaatan modal intelektual perusahaan. Hasil penelitian yang dilakukan oleh Maesaroh (2015) dan Faradina (2016) menyatakan bahwa modal intelektual berpengaruh positif signifikan terhadap ROA. Hal ini berarti semakin baik perusahaan dalam mengelola modal intelektualnya makan akan meningkatkan kinerja keuangan perusahaan. Demikian juga penelitian Untara (2014) bahwa VACA, VAHU, dan STVA berpengaruh signifikan terhadap ROA. Berdasarkan uraian tersebut, maka hipotesis dalam penelitian ini adalah sebagai berikut:

$\mathrm{H}_{1}$ : Modal intelektual berpengaruh terhadap kinerja keuangan perusahaan yang terdaftar di indeks Kompas100.

\section{Kerangka Pemikiran}

\section{Gambar 1. Kerangka Pemikiran}

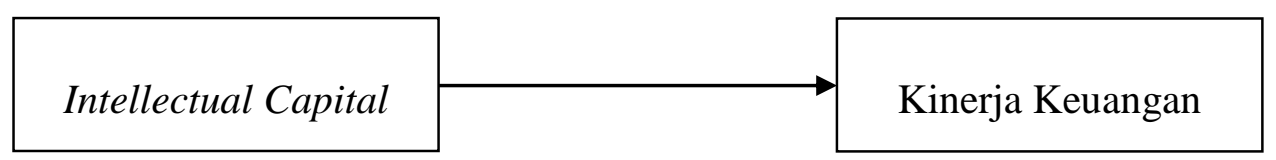

\section{METODE PENELITIAN \\ Jenis dan Sumber Data}

Jenis data yang digunakan dalam penelitian ini adalah data sekunder yaitu data yang diambil dari laporan tahunan perusahaan periode 2015 - 2017. Data dalam penelitian ini diambil dari laporan keuangan perusahaan yang terdaftar di BEI, Indonesian Capital Market Directory dan Galery Investasi Unika Musi Charitas Palembang.

\section{Populasi dan Sampel}

Populasi yang digunakan dalam penelitian ini adalah seluruh perusahaan yang terdaftar dalam indeks Kompas100 yang ada di Bursa Efek Indonesia tahun 20152017. Sedangkan pemilihan sampel dalam penelitian ini adalah dengan menggunakan metode purposive sampling dengan kriteria berikut :

1. Perusahaan yang terdaftar dalam indeks Kompas100 yang terdaftar di BEI(IDX) pada periode penelitian yaitu tahun 2015-2017.

2. Perusahaan yang menggunakan mata uang rupiah dalam penyajian laporan keuangan perusahaannya 
3. Perusahaan yang terdaftar dalam indeks Kompas 100 di Bursa Efek Indonesia yang selama periode pengamatan tidak mengalami kerugian.

\section{Metode Pengumpulan Data}

Metode pengumpulan data yang digunakan dalam penelitian ini adalah menggunakan studi pustaka yaitu suatu cara memperoleh data dengan cara membaca, mempelajari buku-buku yang berhubungan dengan masalah yang dibahas.

\section{Definisi Operasional dan Pengukuran Variabel Variabel Independen $(X)$}

Variabel independen adalah variabel yang mempengaruhi atau menjadi Variabel independen dalam penelitian ini adalah Intellectual Capital (Modal intelektual). Pengukuran modal intelektual didasarkan pada nilai tambah (value added) dengan menggunakan pendekatan Value Added Intellectual Coefficient (VAIC). Pulic (1998) dalam Ulum dkk (2008), pendekatan VAIC dirancang untuk menyajikan informasi mengenai efisiensi penciptaan nilai dari aset berwujud dan aset tidak berwujud yang dimiliki perusahaan. Perhitungan VAIC melibatkan 3 komponen, yaitu Value Added Capital Employed (VACA), Value Added Human Capital (VAHU) dan Structural Capital Value Added (STVA) yang dimulai dengan kemampuan perusahaan dalam menciptakan value added. Value added merupakan indikator yang paling objektif untuk menilai keberhasilan bisnis dan menunjukkan kemampuan perusahaan dalam usaha penciptaan nilai. VAIC diukur dengan rumus:

$$
V A I C_{t}=V A H U_{t}+S T V A_{t}+V A C A_{t}
$$

Keterangan:

$$
\begin{aligned}
& \text { VAIC }_{\mathbf{t}}=\text { Value added intellectual coefficient pada } \mathrm{t} \\
& \text { VAHU }_{\mathrm{t}}=\mathrm{VA}_{\mathrm{t}} / \mathrm{HC}_{\mathrm{t}} ; \text { Value Added Human Capital pada } \mathrm{t} \\
& \text { STVAt }=\mathrm{SC}_{\mathrm{t}} / \mathrm{VAt} \text {; Structural Capital Value Added pada } \mathrm{t} \\
& \text { VAt }=\mathrm{OUT}_{\mathrm{t}}-\mathrm{IN}_{\mathrm{t}}=\mathrm{OP}_{\mathrm{t}}+\mathrm{EC}_{\mathrm{t}}+\mathrm{D}_{\mathrm{t}}+\mathrm{A}_{\mathrm{t}} \text {; VA merupakan } \\
& \text { sales dikurangi dengan Input }\left(\mathrm{IN}_{\mathrm{t}}\right) \text { yang dihitung dari } \\
& \text { atau bisa juga perhitungan antara operating income }\left(\mathrm{OP}_{\mathrm{t}}\right) \text {; } \\
& \left(\mathrm{A}_{\mathrm{t}}\right) \\
& \mathbf{H C}_{\mathbf{t}}=\text { total salary dan wages pada } \mathrm{t} \\
& \mathbf{S C}_{\mathbf{t}}=\mathrm{VA}_{\mathrm{t}}-\mathrm{HC}_{\mathrm{t}} ; \text { structural capital pada } \mathrm{t} \\
& \mathbf{C E}_{\mathbf{t}}=\text { book value of the net assets pada } \mathrm{t}
\end{aligned}
$$$$
\text { VACA }_{\mathrm{t}}=\mathrm{VA}_{\mathrm{t}} / \mathrm{CE}_{\mathrm{t}} ; \text { Value Added Capital Employed pada } \mathrm{t}
$$$$
\text { perhitungan dari Output }\left(\mathrm{OUT}_{\mathrm{t}}\right) \text { yang dihitung dari total }
$$$$
\text { bought-in materials atau cost of goods or services sold; }
$$$$
\text { employee costs }\left(\mathrm{EC}_{\mathrm{t}}\right) \text {; depreciation }\left(\mathrm{D}_{\mathrm{t}}\right) \text {; dan amortization }
$$

\section{Variabel Dependen (Y)}

Variabel dependen dalam penelitian ini adalah kinerja keuangan perusahaan. Kinerja keuangan perusahaan mencerminkan keadaan keuangan perusahaan pada jangka waktu tertentu. Kinerja keuangan perusahaan pada penelitian ini diukur menggunakan rasio Return On Assets (ROA). Menurut Riyanto (2008) dalam Wijayani (2017), ROA merupakan rasio profitabilitas yang mengukur kemampuan perusahaan memperoleh laba bersih dengan aset yang dimilikinya dengan rumus yakni:

ROA = Laba Bersih Setelah Pajak : Total Aset 


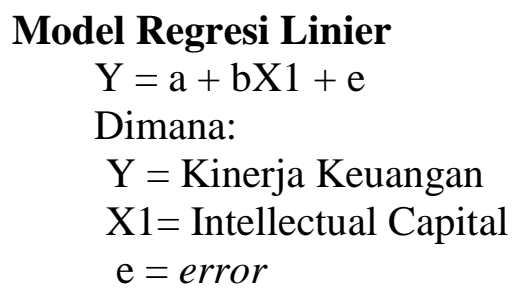

\section{Pengujian Asumsi Klasik}

Pengujian asumsi klasik bertujuan untuk mengetahui dan menguji kelayakan atas model regresi yang digunakan untuk penelitian ini. Pengujian ini juga dimaksud untuk memastikan bahwa didalam model regresi yang digunakan tidak terdapat masalah asumsi klasik seperti normalitas, autokolerasi, heteroskedastisitas dan multikolinearitas.

\section{Uji Hipotesis}

Uji statistik $\mathrm{t}$ menunjukkan seberapa jauh pengaruh variabel bebas secara individual dalam menerangkan variabel terkait (Ghozali, 2016). Dasar pengambilan keputusan adalah:

a. Jika t-hitung < t-tabel, maka variabel bebas secara individual tidak berpengaruh terhadap variabel terikat (hipotesis ditolak)

b. Jika t-hitung > t-tabel, maka variabel bebas secara individual berpengaruh terhadap variabel terikat (hipotesis diterima)

Uji t dapat juga dilakukan dengan melihat nilai signifikansi t masing-masing variabel pada output hasil regresi menggunakan SPSS dengan Significance level 0.05 $(a=5 \%)$. Jika sig $>0.05$ maka hipotesis ditolak tetapi jika sig $<0.05$ maka hipotesis diterima.

\section{HASIL PENGUJIAN HIPOTESIS Data Penelitian}

Tabel 1 Data Penelitian

\begin{tabular}{lc}
\hline \multicolumn{1}{c}{ Keterangan } & Jumlah (firm years) \\
\hline Data (Observasi) Penelitian pertahun & 49 \\
Data (Observasi) akhir & 147 \\
\hline
\end{tabular}

Data yang diperoleh pada penelitian ini adalah sebanyak 49 firm years. Data tersebut didapatkan dari Bursa Efek Indonesia berupa perusahaan indeks kompas 100 yang terdaftar di BEI. Untuk melakukan pengujian dikalikan 3 tahun sesuai dengan pengamatan penelitian. Maka dari itu, data observasi akhir yang digunakan untuk pengujian adalah sebanyak 147 firm years.

\section{Uji Asumsi Klasik}

Pengujian asumsi klasik yang dilakukan dalam penelitian ini adalah uji normalitas, autokolerasi, heteroskedastisitas dan multikolinearitas. Hasil pengujian asumsi klasik menunjukkan bahwa data yang digunakan dalam penelitian ini telah lolos pada pengujian asumsi klasik, yaitu uji normalitas, autokolerasi, heteroskedastisitas dan multikolinearitas.

\section{Uji Hipotesis}

Tabel 3. Hasil Uji Hipotesis

\begin{tabular}{lll}
\hline Model & Sig. & Keterangan \\
\hline VAIC & 0,000 & Hipotesis diterima \\
\hline
\end{tabular}


Hasil pengujian hipotesis pada penelitian ini mengindikasikan bahwa perusahaan indeks Kompas 100 telah berhasil memanfaatkan Intellectual Capital yang dimilikinya sehingga dapat meningkatkan kinerja keuangan perusahaan. Hal ini juga didukung dengan teori berbasis sumber daya, dimana apabila perusahaan bisa memanfaatkan sumber daya dengan baik dan benar maka perusahaan dapat menciptakan keunggulan kompetitif bagi suatu perusahaan sehingga kinerja keuangan perusahaan juga akan meningkat. Semakin tingginya Intellectual Capital perusahaan, maka semakin tinggi kinerja keuangan yang akan dicapai perusahaan. penelitian ini sejalan dengan penelitian yang dilakukan oleh Pratama (2018), Pratama dan Wibowo (2017), Pratama (2016), dan Faradina dan Gayatri (2016) yang menyatakan bahwa modal intelectual berpengaruh positif terhadap ROA.

Hasil penelitian ini juga sesuai dengan resource-based theory yang menjelaskan bahwa IC adalah sumber daya yang merupakan inti dari penciptaan nilai dan keunggulan kompetitif bagi perusahaan (Barney, 1991). Menurut Chen et al. (2005) dan Wang (2008), keunggulan kompetitif berkelanjutan dari IC akan memungkinkan perusahaan untuk mengalahkan pesaing dan juga menciptakan nilai tambah, sehingga dapat berkontribusi pada kesuksesan perusahaan.

\section{SIMPULAN, KETERBATASAN DAN SARAN Kesimpulan}

Penelitian ini digunakan untuk menguji pengaruh Intellectual Capital terhadap Kinerja Keuangan Perusahaan pada perusahaan kompas 100 yang terdaftar di Bursa Efek Indonesia. Hasil pengujian hipotesis (uji-t) membuktikan bahwa Intellectual Capital berpengaruh terhadap Kinerja Keuangan Perusahaan. Hal ini berarti, semakin baik Intellectual Capital yang dimiliki oleh perusahaan kompas 100, maka akan menyebabkan kinerja keuangan perusahaan meningkat.

\section{Keterbatasan}

Dalam melakukan penelitian ini, peneliti memiliki beberapa keterbatasan antara lain: Saran yang bisa dimasukkan dalam keterbatasan adalah jika kita ingin mengukur intellectual capital terhadap kinerja keuangan harus dilihat bahwa perusahaan menerapkan intellectual capital pada dasarnya pasti akan mengeluarkan biaya tambahan sehingga akan menyebabkan kinerja keuangan perusahaan menurun karena perusahaan harus mengeluarkan biaya tambahan dalam melaksanakan ini. Ada baiknya intellectual capital dikaitkan dengan nilai perusahaan dengan asumsi bahwa penerapan ini memang mengeluarkan biaya tetapi nilai perusahaan dapat meningkat dimata stakeholder.

\section{Saran}

Berdasarkan keterbatasan di atas, maka peneliti memiliki saran sebagai berikut:

1) Untuk penelitian selanjutnya dapat menambah variabel lain yang dapat mempengaruhi kinerja keuangan seperti kebijakan deviden, struktur kepemilikan, ukuran perusahaan, dan variabel lainnya yang bisa memperluas hasil dari penelitian selanjutnya.

2) Untuk mengukur kinerja dapat digunakan alternatif pengukuran yang lain seperti ROI, EPS, DER, ataupun proksi lain yang biasa digunakan untuk mengukur kinerja.

\section{DAFTAR PUSTAKA}

Andriana, Denny. 2014. Pengaruh Intellectual Capital Terhadap Kinerja Keuangan Perusahaan (Studi Pada Perusahaan Pertambangan dan Manufaktur yang Terdaftar di Bursa Efek Indonesia 2010-2012). Jurnal Riset Akuntansi dan Keuangan, Vol. 2 No.1 Hal 251-260. 
Angela, Chrystel Putri. 2016. Pengaruh Intellectual Capital dan Good Corporate Governance Terhadap Kinerja Perusahaan Perbankan. Skripsi. Prodi Akuntansi Universitas Katolik Musi Charitas. Palembang.

Aprisa, Rima. 2016. Pengaruh Ukuran Perusahaan, Profitabilitas, Tipe Auditor dan Tipe Industri Terhadap Pengungkapan Modal Inteletual (Studi Empiris Pada perusahaan yang Termasuk Dalam Indeks Kompas 100 Tahun 2014 Buesa Efek Indonesia). JOM Fekon, Vol.3 No.1 (Februari). Fakultas Ekonomi Universitas Riau, Pekanbaru.

Faradina, Ike dan Gayatri. 2016. Pengaruh Intellectual Capital dan Intellectual Capital Disclosure Terhadap Kinerja Keuangan Perusahaan. E-Jurnal Akuntansi Universitas Udayana, Vol.15.2. Mei (2016). Hal 1623-1653.

Ghozali, Imam dan Anis Chariri. 2007. Teori Akuntansi. Badan Penerbit Universitas Diponegoro. Semarang.

Ghozali, Imam. 2016. Aplikasi Analisis Multivariete dengan Program IBM SPSS 23. Edisi 8. Universitas Diponegoro: Semarang.

Ikatan Akuntan Indonesia. 2016. Pernyataan Standar Akuntansi Keuangan No. 19. Jakarta: Salemba Empat.

Maesaroh, Siti dan Yuliastuti Rahayu. 2015. Pengaruh Modal Intelektual Terhadap Kinerja Keuangan Pada Perusahaan Manufaktur. Jurnal Ilmu \& Riset Akuntansi, Vol. 4 No. 11. Hal 1-18.

Nugroho, Ahmadi. (2012). Faktor-faktor yang Mempengaruhi Intelectual Capital Disclsure. International Jurnal of Business and Social Sciences. Val. 3, No. 15, pp. 307-310.

Pratama, B. C. 2016. The Impact of Intellectual Capital of Indonesian's High-Tech Company on Firm's Financial and Market Performance. International Journal of Academic Research in Accounting, Finance and Management Sciences. Vol. 6 (4): 73-81.

Pratama, B. C. 2018. Family Ownership Role in Strengthening the Relationship Between Intellectual Capital and Financial Performance: Research in HighTech Firms in Indonesia and Philippines. Advances in Social Science, Education and Humanities Research. Vol. 231: 326-329.

Pratama, B. C. dan H. Wibowo. 2017. Family Ownership and the Entrenchment Effect on Intellectual Capital Utilization: A Study of High-Technology Companies in Indonesia Dealing with the ASEAN Economic Community (AEC). Jurnal Akuntansi dan Investasi. Vol. 18 (2): 222-230.

Sawarjuwono, T., dan Kadir, A. P. 2003. Intellectual Capital: Perlakuan, Pengukuran dan Pelaporan (Sebuah Library Research). Jurnal Akuntansi dan Keuangan, Vol. 5. No. 1. Hal 35-57.

Ulum, dkk. 2008. Intellectual Capital, dan Kinerja Keuangan Perusahaan : Suatu Analisis dengan Pendekatan Partial Least Squares. Simposium Nasional Akuntansi XI. Pontianak.

Ulum, Ihyaul. 2008. Intellectual Capital Performance Sektor Perbankan di Indonesia. Jurnal Akuntansi dan Keuangan, Vol. 10. No. 2. Hal 77-84.

Ulum, Ihyaul. 2012. Investigasi Hubungan Antara Kinerja Modal Intelektual dan Praktik Pengungkapannya dalam Laporan Tahunan Perusahaan. Jurnal Ekonomi Bisnis, Vol. 17 No. 1 Hal 36-45.

Untara, Andini Permata dan Titik Mildawati. 2014. Pengaruh Modal Intelektual Terhadap Kinerja Keuangan Perusahaan Perbankan yang Terdaftar di BEI. Jurnal Ilmu dan Riset Akuntansi, Vol. 3 No.10 Hal 1-15.

Walidayni, Nur Amalia. 2017. Modal Intelektual Sebagai Tolak Ukur Perusahaan. (http://www.kompasiana.com). Diakses 1 Maret 2018. 
Wijayani, Dianing Ratna. 2017. Pengaruh Intellectual Capital Terhadap Kinerja Keuangan Perusahaan Publik Di Indonesia (Studi Empiris Pada Perusahaan Manufaktur di BEI 2012-2014). Jurnal Riset Akuntansi dan Bisnis Airlangga, Vol. 2. No. 1 (2017) Hal 97-116. 